\title{
Wishful thinking. The attitude of Polish government towards immigration after 2015
}

\begin{abstract}
The purpose of this article is to analyze Polish migration policy after 2015. The author would like to show discrepancies between the political declarations and reality. Its purpose is also to show the position of the Law and Justice government regarding the EU's policy on solving the migration crisis and Poland's openness to admitting refugees/immigrants. The article proposes the thesis that the Polish government's migration policy from 2015-2019 was inconsistent.
\end{abstract}

Key words: immigrants, refugees, relocation, Polish migration policy

$\mathbf{T}$ he migration crisis in Europe coincided with parliamentary elections in Poland and the Law and Justice (PiS) party taking power. The migration crisis left its mark on the election campaign in 2015 and the decisions of the new government on migration issues, which had not been considered to be an important element of state policy before. Decisions taken by the European Union in 2015 divided the Polish political scene. Opponents to relocation and resettlement appeared, along with supporters of this policy.

The purpose of this article is to show discrepancies between the political declarations and reality over the period from October 2015 to July 2019. The beginning of the period analyzed is marked by the 2015 parliamentary elections won by Law and Justice, which thereby assumed responsibility for drafting migration policy. The end is determined by the completion of the analysis of materials for the purpose of this paper. The article proposes the thesis that the migration policy of the Polish government after 2015 has been inconsistent and reveals a discrepancy between the declarations of the ruling party and reality. When examining the above issues, the following research questions are justified: what was the position of the PiS government regarding relocation and resettlement; is Poland open to refugees/immigrants; how many foreigners are staying in Poland according to selected statistics of the Office for Foreigners; how does the government help people in need of international protection; and, what issues aroused conflicts within PiS regarding migration? The interdisciplinary approach to the phenomenon studied here has required various research methods to be employed, including the institutional-legal, decision-making, systemic and statistical methods as well as source analysis.

\section{Refusal to participate in the European relocation system}

With the advent of the migration crisis in Europe the issue of migration became a political topic in Poland. This was mainly due to the EU adopting the mechanism of relocation and resettlement of people seeking international protection, under which a total 
of 7,082 people were intended to arrive in Poland. When the Prime Minister of Poland Ewa Kopacz agreed to admit them, deputy Beata Szydło said this was a "scandal." In her opinion, the mechanism of relocation and resettlement was being supported, damaging the security of the state and without the consent of the Polish society. Additionally, Szydło was of the opinion that these mechanisms would trigger further waves of immigration (Akune, JK, 2015). PiS members warned that relocation and resettlement could result in a "social catastrophe" as well as pose a threat to the cultural and moral order (Szef MSWiA, 2017).

After the election, Prime Minister Beata Szydło, dedicated one paragraph to the matter of refugees in her exposé. She appealed to solidarity - to sharing what is good, and to a willingness to help when extraordinary or dangerous events take place (such as major natural disasters, terrorist or military threats). According to the Prime Minister, solidarity is something different to an attempt to export problems that "certain states have created for themselves without any involvement of others who are to be burdened with them" (Exposé, 2015). After the attacks in Paris and Brussels, the Prime Minister stated on the Superstacja TV channel that she did not believe it feasible "for Poland to admit immigrants at the moment" (Szydlo, 2016a). According to the spokesperson for the government, Rafał Bochenek, this would continue as long as the procedures related to the admission and verification of immigrants were not working (Rzad, 2016).

PM Szydło considered it important that solidarity within the EU be based on "sound principles, respecting the sovereignty and the opinion of each member of the community" (Szydło, 2016b), stressing at the same time that Poland should ensure security for Poles. She acknowledged an obligation to help all Poles who wanted to return to their homeland. She indicated that the EU lacked systemic solutions to deal with the inflow of immigrants, that the obligation to admit persons in need of international protection was not well understood and that the responsibility for the admission of immigrants was being transferred to other states (Szydło, 2015).

Opposition to the EU Council's decision on the relocation of 160,000 refugees was expressed in the resolution of the lower chamber of the Polish Parliament, the Sejm, adopted on April 1, 2016 and drafted on the initiative of PiS deputies. The resolution called for the strict observance of the criteria of Poland's refugee policy (especially involving the protection of single women, children, large families and religious minorities) and leaving the instruments of refugee policy in the hands of the state. This resolution supported the idea of ensuring and financing humanitarian aid in conflict areas and in neighboring countries (Uchwala, 2016a). The attitude expressed in the above document was upheld in the resolution of December 2, 2016 (Uchwata, 2016b). At the same time, the "proposal to establish a corrective refugee allocation mechanism" presented in a draft regulation of the European Parliament and the Council amending the regulation of 26 June 2013 (Ibid.) was opposed. Additionally, in another resolution, passed on May 20, 2016, "the attempts to impose a decision on immigrants on Poland" were considered a violation of sovereignty, of European values and of the EU's subsidiarity principle, a threat to social order, security of citizens, cultural heritage and to national identity (Uchwata, 2016c).

The Polish government was consistent in refusing to admit people seeking international protection as part of relocation. At the informal summit of EU Heads of State and Government in Salzburg in September 2018, Prime Minister Mateusz Morawiecki 
emphasized that Poland had not changed its position. Like other states in the Visegrad group, it continued to oppose forced relocation, preferring voluntary decisions by individual states (Premier, 2018a). An additional argument to refuse to admit foreigners under relocation was the lack of a guarantee of the appropriate level of security in relation to these people. The Polish Prime Minister addressed the matter of foreign policy during a meeting with Polish ambassadors in July 2018, and pointed out, among other things, that solidarity with political refugees, victims of conflicts and host countries in need was necessary, and that Poland would not shirk from it. However, he did not agree for these slogans to be used in an attempt to "impose solutions that are impractical and harmful" (Premier, 2018b). On-site assistance was considered more effective, as it allows the largest number of victims to be reached. Hence, transfers of foreigners as part of resettlements, relocations and ad hoc humanitarian evacuation were not the "right" solution, as emphasized by Renata Szczęch, Undersecretary of State in the Ministry of the Interior and Administration (Szczęch, 2018).

Poland's refusal to accept persons in need of protection under the European relocation system forced the European Commission to initiate the procedure for non-compliance with EU law against Poland. Hungary and the Czech Republic were also brought before the EU Court of Justice. With reference to this, the European Commissioner for Migration, Home Affairs and Citizenship, Dimitris Avramopoulos, said that "relocation is not a choice. It is a legal decision, with legal obligations, agreed on collectively, and which has to be carried out collectively, without exceptions" (Strzępka, 2017). VicePresident of the European Commission, Frans Timmermans, justified this decision by the fact that these states had not indicated that they would respect legal obligations in this area in order to demonstrate solidarity with Greece and Italy (Merkel, 2018). President of Poland, Andrzej Duda "absolutely negatively" assessed an attempt to impose penalties for the lack of consent to import, detain and imprison immigrants in Poland "by force" (Prezydent, 2017). Eventually, the case was referred to the court in December 2017. The first hearing took place on May 15, 2019. The opinion of the Advocate General of the Court of Justice will be delivered on July 29, 2019.

The system of relocation of persons in need of international protection was planned to operate until September 26, 2017. This followed from Art. 13(2) of the decision of the EU Council of September 22, 2015 (Decision, 2015). However, the European Commission resolved to continue this mechanism for as long as people who require international protection have not been relocated from Greece and Italy (Potyrała, 2018, p. 83). Despite the above decision, and an earlier indication of the implementation schedule for the relocation mechanism for those who needed it, Undersecretary of State Renata Szczęch emphasized that Poland's attitude to the automatic relocation mechanism was "right, because the European Union will withdraw from this program" (Szczęch, 2018). At this point, it should be noted that, thinking about the future, the European Commission suggested in its communication of December 7, 2017 that the compulsory relocation mechanism should continue in "emergency situations," and, in "less challenging" cases, the principle of voluntary commitments should apply (Communication, 2017). Yet member states rejected the compulsory relocation mechanism.

In the opinion of PiS representatives, the lack of approval for relocation and resettlement was dictated not only by the threat of a growth in crime and terrorism, and a threat 
to the cultural order, but also by an aversion to taking responsibility for decisions on migration taken by other countries. In the opinion of PiS Chairman, Jarosław Kaczyński, it was Germany that had caused the migration crisis, which was therefore Germany's problem. Kaczyński asked in the Polish Parliament whether a "government under foreign external pressure, and without the nation's explicit consent, can make decisions that are most likely to have a negative impact on our lives, our everyday activities, our public life, public space, our real sphere of freedom and, finally, our security" (Raport, 2015, p. 13). The PiS Chairman warned against immigrants who would not respect Polish law and customs and could establish zones in which Sharia law would apply, as was supposedly the case in Sweden (Ibid., pp. 13-14).

In 2017, at the 5th PiS program congress, Jarosław Kaczyński also stated that Poles "have not exploited the countries from which refugees come to Europe, we have not used their labor force nor brought them to Europe, and that is why we have full moral right to tell them: no" (Wystapienie, 2017). There is no reason why Poles should radically lower their standard of living. The presence of refugees would damage "everyday security" and trigger economic problems.

\section{Aiding those in need on site}

After the 2015 elections, the Polish government resolved to extend aid to people suffering from armed conflicts either on-site or in neighboring countries, instead of admitting them to Poland in compliance with the principles determined by the European Commission. This position was stated in the parliamentary resolution of April 1, 2016 (Uchwała, 2016a). A PiS deputy, Szymon Szynkowski a.k.a. Sęk, said in the course of the debate that this was a moral obligation that Poland and that the PiS government would not shirk it (Sprawozdanie, 2016, p. 240).

On-site aid involves humanitarian aid and development assistance. The former consists of providing assistance, care and protection to populations suffering from armed conflicts, natural disasters and other humanitarian crises caused by man or nature (Article 2(2), Ustawa 2019). Development assistance includes activities undertaken by government administration bodies for developing countries and their societies. It involves promoting the development of democracy and civil society, and supporting social and economic development, activities to reduce poverty, improve health, education and the professional qualifications of the population (Article 2(1), ibid.). The transfer of funds under the aforementioned assistance was carried out, for example, by diplomatic missions, Polish non-governmental organizations, and government administration bodies in the framework of bilateral and multilateral cooperation with humanitarian organizations, specialized EU and UN agencies and institutions.

Recognizing the importance of aiding victims of armed conflicts, Prime Minister Mateusz Morawiecki decided to establish, in the office of the Prime Minister, a Department for Humanitarian Aid and the ministerial office of a member of the Council of Ministers responsible for humanitarian aid and refugee issues; the office was subsequently assumed by Beata Kempa. The detailed scope of her duties was regulated by an ordinance of January 5, 2018, and included, among other things, issues related to supporting hu- 
manitarian aid activities, cooperation with non-governmental organizations, churches and religious associations in the field of humanitarian aid, promotion and dissemination of issues related to humanitarian aid, needs analysis and identification of the directions of activities in the field of humanitarian aid (Rozporzadzenie, 2018).

Minister Beata Kempa decided that the government should not economize on aiding Syrians affected by the war. They needed effective aid "rather than a handful of spectacular instances" of help, she said (Walcza, 2017). Mateusz Morawiecki confirmed that Poland had spent "several hundred million zlotys" for humanitarian aid (Wychowatem sie , 2018) and had been "the most generous state" since the emergence of the Economic Resilience Initiative (Wywiad, 2016). An analysis of OECD statistics on Poland's involvement in development assistance, though, demonstrates that 0.14 percent of GNI (the ratio of Official Development Assistance, ODA, to Gross National Income) had been allocated for this purpose in 2018. Only Slovakia and Greece were behind, with 0.13 percent of GNI (Official, 2018). Poland is not among the top countries in this area (unlike Sweden, Luxembourg, and Norway) then. However, Poland has committed to increase its share to 0.33 percent of GNI by 2030, which is expected to bring it closer to the average Official Development Assistance, that amounted to 0.30 percent in 2017 (More, 2017).

Poland was involved in providing aid through participation in numerous international projects. For example, in February 2016, Prime Minister Beata Szydło took part in the Supporting Syria and the Region Conference. Its goal was to raise funds for Syria (the Syria Humanitarian Response Plan). Before the conference, the PM declared that a contribution of $€ 3$ million would be made to the international fund for support of Syria and the region, which was afflicted by civil war (Premier, 2016). During the conference, different states declared to pay a total of \$12 billion from 2016-2020 (Syria, 2016). The analysis of payments made by the Polish government to the fund in question in 2016-2018 reveals a large disparity. During the first two years, Poland's share in the total amount transferred by states and organizations amounted to 0.1 percent (in 2016 - \$1,191,097, one year later - \$1,690,247). In 2018, Poland did not transfer anything. Three countries among the founders were the leading contributors: Germany, the United Kingdom and the USA. ${ }^{1}$ During the third Supporting Syria and the Region Conference, organized in March 2019, the international community maintained its support for Syria and neighboring countries and provided funding of $€ 6.16$ billion in 2019 and $€ 2.09$ billion in 2020. Poland declared a payment of $€ 4$ million in 2019, and made no promises for the following year. By comparison, Poland's neighbors declared the following amounts in 2019: the Czech Republic - €21.4 million, Slovakia - €6.1 million, Lithuania - $€ 2.6$ million, and Germany - $€ 1.3$ billion (Co-chairs, 2019).

In addition to this fund, the Polish government provided assistance by making payments to the Facility for Refugees in Turkey. EU member states pledged to transfer $€ 3$ billion to Turkey ( $€ 1$ million from the EU budget, and the remaining amount from membership fees depending on the share of EU GDP). The amount to be paid by Poland was set at $€ 57$ million in 2016 (Instrument, 2016). By comparison, the contribution of

${ }^{1}$ Own calculations based on data for 2016-2018. https://fts.unocha.org/appeals/501/donors? order=total_funding\&sort=desc, https://fts.unocha.org/appeals/526/donors?order=total_funding\&sort= desc, https://fts.unocha.org/appeals/629/donors?order=total_funding\&sort=desc, 2.05.2019. 
Germany amounted to $€ 427.5$ million, the United Kingdom - $€ 327.6$ million, and France $-€ 309.2$ million (Ibid.).

In December 2017, Poland signed an agreement with the European Investment Bank regarding participation in the Economic Resilience Initiative (ERI). Its aim is to support the economies of Southern Neighborhood and Western Balkan countries (including investment financing, development of the private sector, job creation in Algeria, Egypt, Jordan, Lebanon, Libya, Morocco, Palestine, Syria, Tunisia, Albania, Bosnia and Herzegovina, Macedonia, Kosovo, Montenegro and Serbia) (Economic, 2019). In 2017, Poland declared a payment of $€ 50$ million (Polska przekazuje, 2017). At the time, this was the biggest contribution, as Italy declared to pay $€ 45$ million, Slovakia - $€ 2$ million, Slovenia - €500,000, and Luxembourg - €400,000 (Bodalska, 2017).

In 2016, the government allocated PLN 124.3 million for humanitarian operations. This amount included PLN 16.4 million transferred through Polish diplomatic missions and non-governmental organizations, and PLN 107.9 million for assistance to be provided by specialized UN and EU humanitarian agencies (including PLN 73.2 million for the Facility for Refugees in Turkey) (Szczęch, 2018). This means that Poland donated PLN 51.1 million on its own initiative in 2016. ${ }^{2}$

Next year, Poland increased its humanitarian aid, spending over PLN 167.4 million, including PLN 106.7 million allocated to the Facility for Refugees in Turkey, PLN 29.3 million for bilateral assistance and PLN 30.5 million for multilateral assistance (Poland, 2018, p. 44). The total amount spent on humanitarian aid in 2017 was comparable to the planned expenses for the Chancellery of the President of Poland (PLN 168.3 million) and much lower than the maintenance of the Chancellery of the Sejm (PLN 481.6 million) (Dochody, 2017). In 2018, the payment for the Facility for Refugees in Turkey amounted to $€ 12,589,311$ (Plan wspótpracy, 2018, p. 32). The package for humanitarian aid in the Middle East under bilateral and multilateral measures amounted to PLN 26,783,831 (Ibid., p. 45).

Thanks to the involvement of Polish NGOs, projects were implemented in the Middle East, in Lebanon, Jordan and Iraq. In February 2018, PM Mateusz Morawiecki paid a visit to Lebanon. Its purpose was to confirm the continuation of assistance for Syrian refugees there, and to undertake new initiatives. Those included $\$ 10$ million for the construction of a housing estate (for around 10,000 people) and houses (for 1,000 people) for refugees in 2018 (Premier, 2018c). Patryk Strzałkowski wrote in an article that in one year since these declarations had been made, the plans had apparently not been implemented (Strzałkowski, 2019).

The Polish Center for International Aid has been involved in helping refugees in Lebanon. Its employees have supported support Syrian refugees in this country since 2012. In 2017, PLN 2,993,416 was transferred for Syrian refugees and the local population in the Bekaa Valley, Lebanon Mountains, Beirut suburbs and Akkar province for aid in winter (Wyniki, 2017). Additionally, a total of PLN 6,248,898 was allocated to improve humanitarian conditions in the Akkar province (access to health care, ensuring accommodation) (Ibid.). The programs financed medical assistance and covered the renovation

2 The amounts were allocated over a longer period of time making it difficult to convert them to a single currency for comparison. In order to avoid miscalculations the author decided to maintain the currencies used in source materials. 
costs of residential premises. As part of the Humanitarian Aid in the Middle East 2018 Contest, co-financed by the Ministry of Foreign Affairs, in total, PLN 5,179,335 was transferred (under modules I and II) in 2018 (Wyniki, 2018), followed by a further PLN $6,566,489$ (under modules I and II) in the next year (Wyniki, 2019a). An open contest, Polish Development Aid 2019, ensured PLN 999,902 (in 2019) and PLN 1,484,251 (in 2020) for development assistance in northern Lebanon (Wyniki, 2019b).

In addition to cooperating with the Polish Center for International Aid, the government also implemented aid projects for Syria with the papal foundation Aid to the Church in Need. On March 1, 2017, Prime Minister Beata Szydło announced that she would support the reconstruction and operation of Syrian hospitals and schools to the amount of PLN 1.5 million from the budget reserve (Rzad, 2017). As part of the cooperation in 2017, 680 apartments were selected for renovation; the cost of this aid was estimated at approximately PLN 4 million (Premier, 2017). In 2017, Aid to the Church in Need alongside the Father Werenfried Foundation transferred PLN 20 million to Syria (Syria).

The Polish government has also declared the transfer of $€ 1.1$ million to the European Union Emergency Trust Fund for stability and addressing the root causes of irregular migration and displaced persons in Africa. The fund was established in November 2015 in Valletta during the EU-Africa summit (Szczyt, 2015; Nadzwyczajny, 2015). In October 2017, at the EU summit, Prime Minister Szydło, declared further aid at PLN 7 million (Akune, 2017).

\section{Opening to refugees/immigrants}

Interviewed on May 24, 2017, President Andrzej Duda declared that "we definitely are not a closed state. We are an open state" (Prezydent, 2017).

The statements made by government members suggest that, despite their negative attitude to relocation and resettlement, they were open to helping refugees/immigrants. During a debate in the European Parliament on January 19, 2016, Prime Minister Szydło announced that Poland had admitted around one million refugees from Ukraine, whom nobody wanted to help. It should be noted that in 2015, the number of applications for international protection submitted by Ukrainian citizens amounted to 2,305 (of whom 2 people were granted refugee status in the first and second instance) (Zestawienie roc$z n e, 2015)$. This statement triggered a response from the Ukrainian ambassador to Poland, Andriy Deshchytsia, who said that these were not refugees but economic migrants (Milion, 2016). Łukasz Łotocki observed that "speaking about one million refugees from Ukraine was a certain semantic abuse" (Łotocki, 2019, p. 357).

Speaking at the Supporting Syria and the Region Conference organized in London at the beginning of February 2016, PM Szydło continued to maintain that Poland had admitted refugees although on this occasion she mentioned a consent to admit only "several hundred refugees" (Premier, 2016). This number concurred with the statistics of the Office for Foreigners that reported that 128 people were granted refugee status in the first and second instance in 2016, which accounted for $1 \%$ of all applications submitted in that year (Zestawienie roczne, 2016). 
In addition to Beata Szydło, Mateusz Morawiecki also spoke about Poland's openness to admitting refugees/immigrants. Interviewed by a CNN journalist in January 2016, during the World Economic Forum in Davos, as the Minister of Development he stated that "we have thousands of immigrants from the east of Ukraine whom we support" (Wywiad, 2016). It can be presumed that the Minister was not referring to migrant workers, but only to people who needed protection; however, this status was not granted to so many Ukrainians in Poland. During his visit to Davos, Morawiecki was also interviewed by Bloomberg Television. Addressing the migration crisis and our contribution to its solution, he stated, among other things, that Poland had admitted 350,000 refugees from Ukraine (Maciejewicz, 2016). Analyzing the statistical data, it can be assumed that Morawiecki was referring to the data on first applications for residence permits submitted by foreigners in Poland. According to Eurostat, in 2014, there were 355,418 applications, including 247,397 submitted by Ukrainians (Residence, 2015).

Interviewed by Trwam Television, on the program Rozmowy niedokończone [Unfinished conversations] (December 2017) after he assumed the office of Prime Minister, Mateusz Morawiecki merely said that Poland had admitted "large numbers of refugees" from war-ridden parts of Ukraine, which the EU failed to notice. He stressed that, in this way, we help to mitigate "tensions on the eastern flank of the EU" (Rozmowy niedkończone, 2017). Ukrainian Minister of Foreign Affairs, Pavlo Klimkin was of a different opinion, though. He said that it was Ukrainians who were helping Poland, supporting its economy (Morawiecki, 2017). Speaking on TVP Info Television in January 2018, the PM stressed Poland's contribution to mitigating tensions on the EU eastern border once more, and said that "we have admitted at least tens of thousands, maybe even well over one hundred thousand refugees from Ukraine but we have not granted them asylum status" (Kozłowska, 2018).

In a conversation with Jean-Claud Juncker on January 9, 2018, PM Morawiecki spoke about the strict rules in granting asylum, the thousands of asylum applications submitted in Poland and the small number of positive decisions (Czaputowicz, 2018). It appears that the PM confused the instrument of asylum with the status of a refugee, or some other instrument of international protection. In Poland, thousands of asylum applications have not been submitted for many years. ${ }^{3}$ According to data from the Office for Foreigners for 2015-2018, the largest number of applications for asylum, 118, was submitted in 2015, followed by the smallest number, 23, one year later (Zestawienie roczne, 2015-2018). Speaking to the European Parliament in Strasbourg on July 4, 2018, the PM gave the number of 1.5 million citizens of Ukraine for whom Poland had become home, including refugees fleeing from Russian aggression. He stressed, however, that "they are not registered as refugees in Poland, but this is so only because our procedures allow them to obtain work permits much more easily and to pursue their own and their families' well-being, while supporting the economy of Poland and the EU" (Debata, 2018). The Ukrainians mentioned by the PM were therefore economic migrants, not those seeking protection. They do not burden the state budget, they support it.

The PM maintained his position on the admission of over one million Ukrainians during an interview for the daily newspaper Le Figaro (No. 162, winter 2018-2019). Refer-

${ }^{3}$ Asylum here refers to Polish internal legislation. In Poland, asylum has a constitutional status regulated by Art. 56 section 1 of the Polish Constitution of 1997. It is not the same as refugee status. 
ring to the issue of immigrants, he reminded readers that Poland had admitted 1.5 million Ukrainians, $10 \%$ of whom had come from the war-torn area. It is not clear, however, who the PM had in mind - the citizens of Ukraine who came looking for employment, or those seeking protection. His statement clearly implied that Poland had provided shelter for 150,000 Ukrainians from war-torn areas (Morawiecki, 2019).

In the opinion of PM Morawiecki, openness was demonstrated not only to Ukrainians but also to Chechens. In a Future of Europe debate organized on June 25, 2018 in the Natolin European Center, and attended by Wolfgang Schäuble (the head of the Bundestag), the PM said that there were over 25,000 people from Chechnya in Poland (Natolin Debate, 2018). Yet the statistics of the Office for Foreigners do not feature a separate category for Chechens who are registered as Russian citizens, 11,415 of whom held valid documents confirming their right to stay in Poland as of January 1, 2018 (Zestawienie roczne, 2018).

Another person denying that Poland was closed to refugees/immigrants was Marek Suski, the head of the political cabinet of the PM. On April 21, 2018, at the Polish Institute in Vienna, during a meeting with the employees of the diplomatic and consular corps, Austrian deputies and representatives of the media Suski stated that "Poland admits the largest number of refugees when it comes to refugees seeking work on the basis of work permits released for the first time" (Spotkanie, 2018). To confirm this, he referred to Eurostat data on residence permits (including extensions) and temporary work permits issued in Poland in 2016, which amounted to 585,000 permits. The number provided by the Minister did not correspond to the number of refugees in Poland. According to the Office for Foreigners, 128 people were granted refugee status in 2016. In addition, refugees did not come to our country in search of work, as assumed by the head of the PM's political cabinet. Suski also quoted Eurostat data from 2016 on first permits for residence issued, excluding the numbers of work permits registered (New high, 2017, p. 2). He compared these numbers to those in the United Kingdom $(865,000)$, Germany $(505,000)$, France $(235,000)$ and Italy $(222,000)$ (Spotkanie, 2018).

According to the Minister of Foreign Affairs Jacek Czaputowicz, Poland has admitted 2,700 immigrants "sent by Western Europe." The Minister said that in an interview for Le Figaro, published on April 5, 2018 (Szef, 2018). He also stated that, due to the low standard of living in Poland, they had left. This triggered a response from the Ministry of Foreign Affairs that explained that the Minister did not mean people who came under the relocation mechanism, but those for whom Poland was the first country to enter the EU, and who applied for international protection in another EU country and, therefore, had to return to Poland under EU law. The Ministry also stated that approximately 3,700 people were transferred to Poland in 2015-2017 (Nie przyjęliśmy, 2018; Oświadczenie, 2018). However, in the interview the Minister did not specify the period of time during which Poland admitted these 2,700 immigrants. His words about Poland admitting immigrants were not welcomed by the right side of the political scene. For instance, deputy Krystyna Pawłowicz and publicist Witold Gadowski expressed their dissatisfaction. In an interview for the website wPolityce.pl, the latter stated that either "the government is lying to the public, or Minister Czaputowicz does not know what he is saying. In either case, we have a sufficient reason to immediately dismiss the Minister. It's a scandal. If immigrants have been admitted without informing the public, the government has broken its election promises and betrayed its citizens" (Nasz, 2018). 
The fact that over one million Ukrainians were admitted to Poland was also confirmed by Mariusz Błaszczak. In October 2017, as the Minister of the Interior and Administration, he argued that "there are over one million of Ukrainian citizens in Poland part of whom have fled the war after Russia invaded their country, and another part are economic migrants. In his opinion, unlike Muslims, they integrate very well" (Merkel, 2018).

This narrative of representatives of the Polish government and some political parties has resulted in the issue of immigrants/refugees being connected in the political debate with the terrorist threat and poorer security. It has also been suggested that their presence will cause the outbreak of various diseases in Poland, as claimed by PiS Chairman Jarosław Kaczyński and the President of Poland Andrzej Duda. Developing an adequate immigration policy has also been impaired by the fact that government representatives have, in their statements, distorted the facts, and informed the public in Poland that large numbers of people who needed international protection have been admitted to Poland.

Despite the anti-immigrant government rhetoric, the number of foreigners in Poland has increased. According to statistics, as of January 1, 2019, the number of foreigners holding valid documents confirming the right of residence in Poland amounted to 372,239 (Zestawienie roczne, 2018). Compared to 2015 , their number increased by 16,370 .

Table 1. Foreigners holding valid documents confirming the right of residence in Poland, 2015-2018

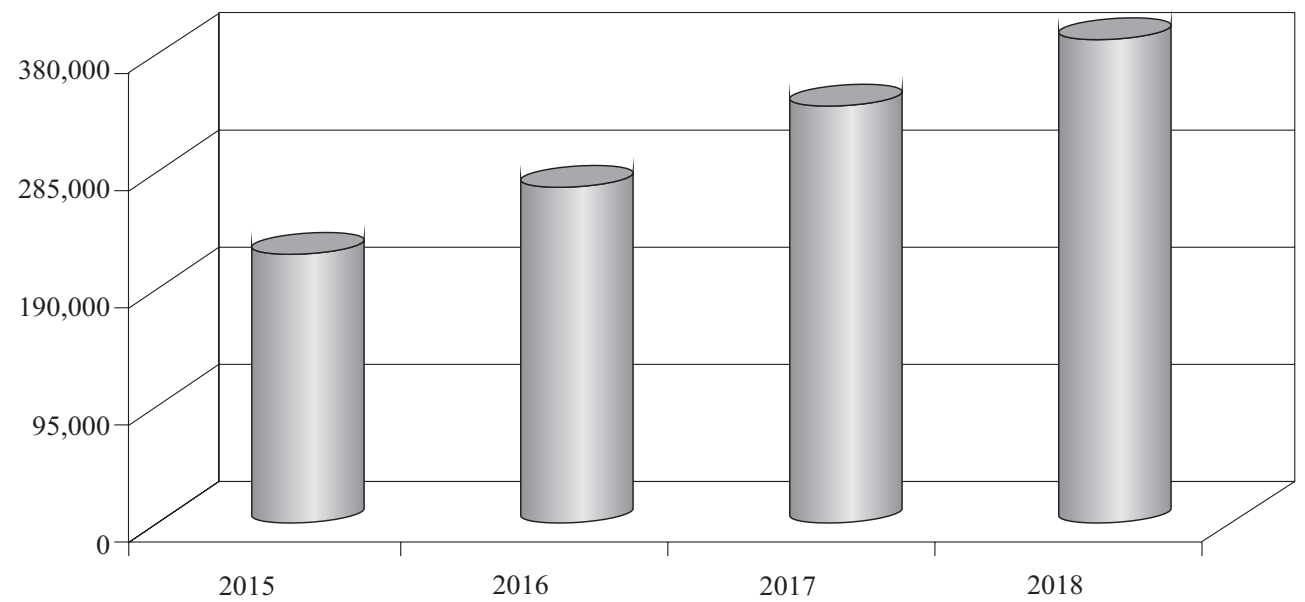

Source: Zestawienie roczne dotyczace postępowań prowadzonych wobec cudzoziemców w 2015, 2016, 2017, $2018 \mathrm{roku}$, https://udsc.gov.pl/statystyki/raporty-okresowe/zestawienia-roczne/, 8.05.2019.

The largest proportion of foreigners holding documents confirming the right of residence in Poland came from neighboring countries, including Ukraine, Germany, Belarus and Russia. In 2015-2018, an increase in the number of citizens from India (by 5,787 people), China (by 3,326 people) and Vietnam (by 3,268 people) (own calculations) was observed. 
In addition to the increase in the number of documents issued confirming the right of residence in Poland, the number of registered work permits also grew. In 2015-2018, it increased by 262,982 (from 65,786 to 328,778) (Dane zbiorcze, 2015, 2018). In 2018, most of them were granted to Ukrainians (72.5\%), Nepalis (6\%) and Belarusians (5.8\%) (own calculations). An analysis of statistics for the number of permits issued shows that, over the four years examined here, the number of job seekers from the following countries increased: Azerbaijan (from 116 to 3,302), Bangladesh (from 319 to 8,341), India (from 1,425 to 8,362), Nepal (from 596 to 19,912), Moldova (from 1,488 to 6,035) and Georgia (from 88 to 2,752) (Dane zbiorcze, 2015, 2018). Taking into account only the first half of 2018, it can be noted that work permits were granted to over 6,800 citizens of Muslim countries (including, for example, Azerbaijan - 1,465, Bangladesh - 2,928, Morocco - 100, Pakistan - 467, Tajikistan - 345, Turkey - 571 and Uzbekistan 975) (Dane zbiorcze za I polowe 2018, 2018). This number is similar to that of people allocated to Poland under the relocation system.

The number of work permits issued should be added the number of foreigners working in Poland on the basis of a declaration of intent to employ a foreigner (1,582 225 declarations in 2018), as well as on the basis of seasonal work permits (138,334 permits registered in 2018).

Table 2. Work permits issued to foreigners and declarations of intent to employ a foreigner, 2015-2018

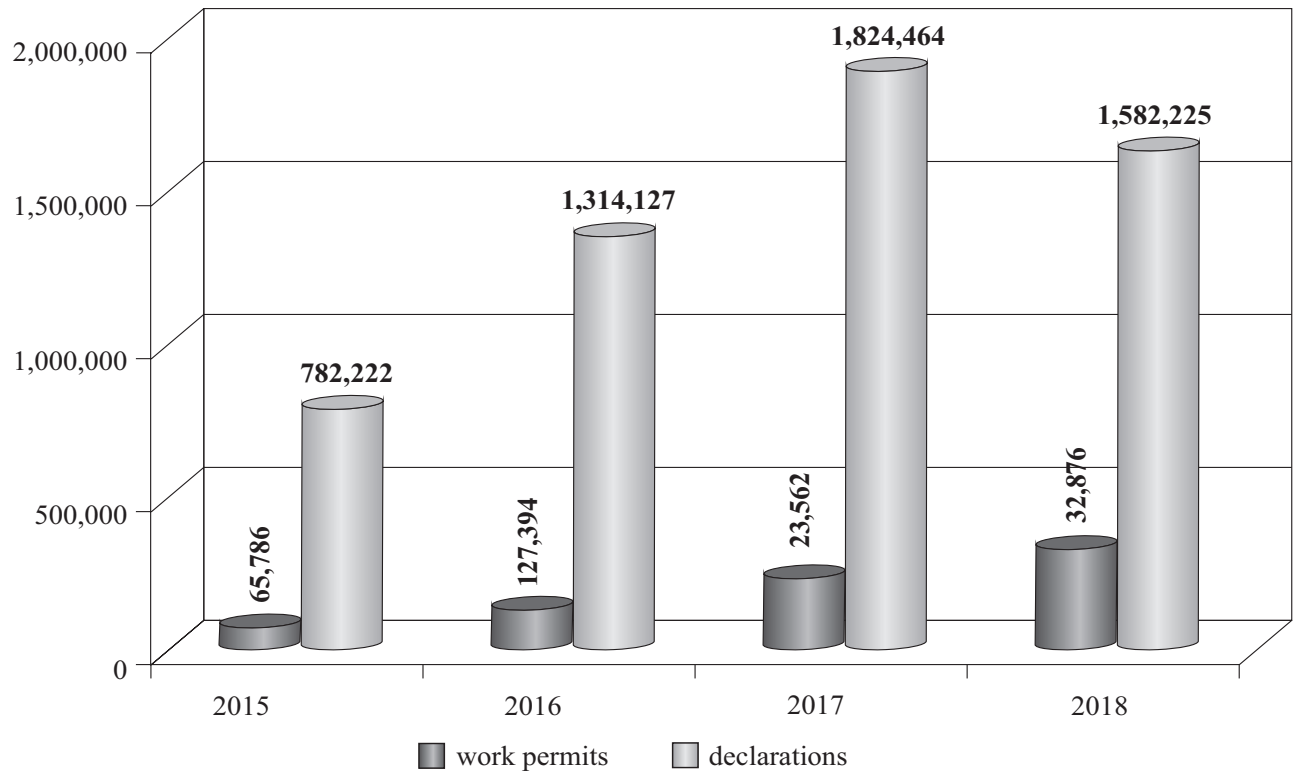

Source: Zezwolenia na pracę cudzoziemców w 2015, 2016, 2017, 2018, http://psz.praca.gov.pl/web/urzad-pracy/-/8180075-zezwolenia-na-prace-cudzoziemcow, 5.05.2019; Oświadczenia o powierzeniu wykonywania pracy cudzoziemcowi, wpisane do ewidencji oświadczeń w 2015, 2016, 2017, 2018, http://psz.praca. gov.pl/web/urzad-pracy/-/8180205-rejestracja-oswiadczen-pracodawcow-o-zamiarze-powierzenia-pracy-cu dzoziemcowi, 5.05.2019; http://psz.praca.gov.pl/web/urzad-pracy/-/8180211-oswiadczenia-o-powierzeniuwykonywania-pracy-cudzoziemcowi-wpisane-do-ewidencji-oswiadczen-obowiazujace-od-2018-r-, 5.05.2019. 
In a conversation about state security on Trwam Television on September 20, 2018, Minister of the Interior and Administration, Joachim Brudziński, observed that there had been an increase in the number of economic migrants, "whose skin color indicated that these are employees from outside of Europe" (Rozmowy, 2018). He explained this fact with the growing demand for workers in the agricultural sector, the growing number of foreign students and the free movement of people within Schengen area. He also stated that cheap labor should be recruited primarily from the countries of "the six," namely Ukraine, Belarus, Russia, Moldova, Armenia and Georgia. He believed that this was the case not only due to their easier access to the labor market, but also to their cultural and linguistic similarity (Ibid.).

According to Eurostat data, in 2017, Poland granted the largest number $(683,228)$ of first permits for foreigner residence in EU countries (First, 2018, p. 2). Poland was followed by Germany (535,446 permits) and the United Kingdom (517,000 permits). One year earlier Poland came second (585,969 permits) only to the United Kingdom $(865,894)$ (New high, 2017, p. 2).

\section{Attitudes to migration inside the Party}

The influx of immigrants to Poland aroused concerns among some members of the ruling party. Krystyna Pawłowicz was among those who, after the interview of the Minister of Foreign Affairs Jacek Czaputowicz in April 2018, expressed her outrage, writing on Twitter: "POLES are AGAINST! WE ARE LYING TO VOTERS! You will make us lose the election!" She reminded readers that PiS had declared in its election platform that Poland would not admit "any migrants from the EU's distribution list," while the Minister talked about 2,700 people sent to Poland from Western Europe (Pawłowicz, 2018a).

Krystyna Pawłowicz also wrote a letter to the Prime Minister and the Minister of the Interior and Administration, Joachim Brudziński. She published its content on Twitter on June 20, 2018 (Pawłowicz, 2018b). She criticized the policy of the government, accusing it of breaking one of the most important election promises, namely not admitting immigrants to Poland. In the letter she wrote, among other things: "Although Law and Justice promised in the election campaign that we would not admit migrants, or so-called refugees, I have been approached - recently in especially large numbers - by our voters who have been watching this situation and who have told me that more and more Muslim migrants and refugees are coming to Poland nevertheless" (Ibid.).

In her letter, deputy Pawłowicz asked sixteen questions, including the following: is it true that Poland has signed a bilateral agreement with Uzbekistan to admit workers from that country to Poland; is it true that hourly rates granted to these foreign employees are much higher than those of Polish employees; is it true that Poland has signed agreements with other Asian countries regarding the admission of employees to Poland; is it true that a Chinese ship that recently arrived in Poland was bringing Chinese workers (Ibid.)?

Deputy Anna Sobecka was another person concerned about the migration policy. On September 10, 2018, she filed an appeal to the Minister of the Interior and Administration regarding economic migrants from the Philippines, India, Bangladesh, Uzbekistan 
and other Asian countries (Interpelacja 23257, 2018). She wrote that admitting economic migrants to Poland raises anxiety among Poles in relation to security, among other things. In connection with this she inquired about (1) the assumptions of current government policy as regards employing workers from Asian countries, (2) the number of employees who are expected to arrive in Poland by 2020, and (3) activities carried out with respect to bringing Poles from the former USSR states and preventing emigration from Poland (Ibid.).

The influx of cheap labor from the Middle and Far East, and Ukraine was also addressed by PiS deputy Barbara Bubula (Interpelacja 26115, 2018). She described to the Prime Minister the emergence of zones inhabited by foreign workers, damaging security in the area and the quality of services provided in companies employing immigrants, and that resulted in dismissals of Poles over 50 years of age. She also stated that "our citizens, voters who support us, expect policies that bravely protect the future sovereignty, independence and the identity of their homeland" (Ibid.). In connection with this, she inquired about halting the arrival of employees from the above-mentioned regions, implementing plans for mass repatriation and introducing incentives for Poles returning from emigration.

Two PiS deputies, Adam Ołdakowski and Jerzy Małecki, also stressed the fact that foreign employees are favored at the expense of Polish citizens. In their opinion, this may have an adverse impact on the economic emigration of Poles, on attitudes towards foreign employees and on deteriorating living standards of Poles (Interpelacja $\mathrm{nr}$ 8801, 2016).

The inquiries from PiS deputies might have been related to the Uzbek Jahon Information Agency reporting on the meeting of the delegation from the Agency for External Migration and Labor Relations of the Ministry of Labor and Labor Relations of Uzbekistan with representatives of the Polish government, the Chamber of Commerce in Poland and entrepreneurs, organized in May 2018 in Warsaw (Взгляд, 2018). The goal of the meeting was to discuss the details of admitting 3,000 migrant workers to Poland and signing a cooperation memorandum with ten Polish companies from the construction, clothing, agricultural and food industries. The employees of the External Work Migration Agency at the Uzbek Ministry of Labor met with the governors of the Lódzkie and Lubelskie regions. Prior to this, they concluded agreements with sixteen Polish companies (including employment agencies) that were tasked with recruiting Uzbek employees (Ibid.). It may be surprising that PiS members were warning Poles against an influx of Muslims, while representatives of the PiS government took part in a meeting aimed at bringing in Uzbek citizens, 90 percent of whom are Muslim.

In addition to the talks with Uzbekistan, negotiations on cooperation regarding the employment of Filipinos in Poland in the IT, construction and elderly care sectors were initiated (Rzad, 2018). They took place in July 2018. The meeting was attended by Stanisław Szwed (Secretary of State at the Ministry of Labor and Social Policy) and Patricia Ann V. Paez (ambassador of the Republic of the Philippines in Warsaw).

The issue of economic immigration to Poland became the reason for dismissing Paweł Chorąży, Deputy Minister of Investment and Development, in September 2018. His dismissal was related to an opinion he expressed on the subject of migration policy during a debate organized by the Jagiellonian Club. He said, among other things, that 
the inflow of immigrants to Poland must increase to maintain the economy at the current level. The former Deputy Minister also argued that Poland "must, and even if it does not want to, it should" want immigrants, because they are behind the prosperity of the countries that have achieved the greatest success (Wiceminister, 2018). Chorąży also claimed that bringing repatriates from the East is expensive and, from the financial point of view, it is more profitable to attract immigrants from Asia or Ukraine to Poland (Szymański, 2018). Although politically incorrect, his statement is justified from an economic point of view. The "incorrectness" was related to the fact that the PiS government preferred repatriation in its migration policy. It considered it a priority to bring in repatriates rather than immigrants from the Middle East or Africa. However, taking into account economic factors, admitting repatriates is quite expensive, which is mainly related to the help they receive to resettle. A repatriate, and every member of their immediate family, can count on financial help from the state budget of up to PLN 6,000, for partial coverage of the costs of renovation, adaptation or furnishing of residential premises (Article 17(2), Ustawa, 2018a). Additionally, the financial assistance provided for the purchase of an apartment has increased to PLN 25,000 for a repatriate and a member of his immediate family (who runs the household together with him) (Article 17b (8a), Ibid.). The Polish state allocates up to PLN 300 a month for rent per repatriate (Article 17b (7), ibid.). The state budget also covers the costs of healthcare services for persons who have obtained Polish citizenship through repatriation; and the head of the district appropriate for the repatriate's place of residence bears the costs of his professional activation (Article 23 (1), ibid.). A repatriate can also receive financial support for his journey or flight to Poland, costs of living (twice the average monthly salary before tax) or costs related to a minor studying in Poland (Article 17 (1), ibid.).

On top of that, holders of the Polish Card ${ }^{4}$ have received financial support pursuant to the amendment to the Law on the Polish Card of January 1, 2017. The new chapter $2 \mathrm{a}$ was added to the Law, which specifies the conditions for granting a cash payment for a period of nine months (Article 8c (1), Ustawa, 2018b) for each family member (including a minor).

To summarize this article, it should be stated that the thesis put forward at the beginning has not been fully confirmed. This is related to the fact that the PiS government has remained consistent and not changed its opinion on the relocation and resettlement of people who require international protection to Poland. Moreover, from the beginning the government has maintained the attitude that people in need should receive aid at the site of conflict or in neighboring states. The inconsistency in the migration policy has primarily been related to the fact that, contrary to the opinions that Poland is closed for foreigners, the number of immigrants arriving in Poland has actually increased. As pointed out above, according to Eurostat statistics, the largest number of first permits for foreigner residence in all EU countries was granted by Poland in 2017. This means that, despite the anti-immigrant government rhetoric, the number of foreigners in Poland has increased. Their number has grown even though the issue of immigrant influx has been associated with that of terrorist threat and reduced security level. Additionally, the statements of

${ }^{4}$ The Card is awarded to persons declaring their belonging to the Polish Nation and meeting the conditions stipulated in Art. 2(1) of the Law of September 7, 2007 on the Polish Card (Ustawa z dnia 7..., 2018b), Dz. U. 2018, item 1272. 
the ruling party's politicians have implied concerns with Poland accepting Muslim immigrants, while government representatives have signed employment agreements with countries where Islam is the dominant religion.

The lack of coherence in Polish migration policy has resulted from the absence of a government document that would define such a policy. This has also translated into pursuing an ad hoc policy and the failure to develop a migration doctrine. This situation is dangerous as it makes Polish migration policy unpredictable.

Poland has recently joined a group of countries with a positive migration balance. Demographic forecasts are not favorable for Poland, and the employment gap is growing. Immigrants may solve these problems. However, their influx, combined with an inadequate immigration policy, including integration policy, and claims that they pose a threat to the security of the state and its citizens may bring unpleasant results.

\section{Bibliography}

Akune, JK (2015), Rzecznik rzadu: Beata Szydto myli interes Polski z interesem PiS, 23.09.2015, TVP Info, https://www.tvp.info/21750766/informacje/polska/rzecznik-rzadu-beata-szydlo-myliinteres-polski-z-interesem-pis/, 15.05.2019.

Akune (2017), Szydło: Polka przekaże prawie 7 mln euro na unijny fundusz dla Afryki, 19.10.2017, http://www.tvpparlament.pl/aktualnosci/szydlo-polska-przekaze-prawie-7-mln-euro-na-unijny-fundusz-dla-afryki/34462359, 16.05.2019.

Bodalska B. (2017), Polska przekaże na rzecz migrantów $50 \mathrm{mln}$ euro, 20.09.2017, https://www. euractiv.pl/section/migracje/news/polska-przekaze-tym-roku-rzecz-migrantow-50-mln-euro/, 16.05.2019.

Взгляд из Польши (2018): трудовые мигранты из Узбекистана отличаются качественной и добросовестной работой, 07.2018, http://www.uzbekistan-geneva.ch/vzglyad-iz-pol-shi-trudovye-migranty-iz-uzbekistana-otlichayutsya.html, 16.05.2019.

Co-chairs'Statement Annex (2019): Fundraising, Supporting the Future of Syria and the RegionBrussels III Conference Brussels, 14 March 2019, https://www.consilium.europa.eu/ media/38579/14-03-2019-pledging-statement_final_rev.pdf, 28.04.2019.

Communication from the Commission to the European Parliament, the European Council and the Council. Commission contribution to the EU Leaders' thematic debate on a way forward on the external and internal dimension of migration Policy, Brussels, 7.12.2017, https:// ec.europa.eu/home-affairs/sites/homeaffairs/files/what-we-do/policies/european-agenda-migration/20171207_communication_on_commission_contribution_to_the_eu_leaders_thematic_debate_on_way_forward_on_external_and_internal_dimension_migration_policy_en.pdf, 7.05.2019.

Czaputowicz ogłosit, że Polska przyjęła 2700 migrantów (2018), TVN24.pl, 11.04.2018, https:// www.tvn24.pl/wiadomosci-z-kraju,3/uchodzcy-w-polsce-czaputowicz-mowi-ilu-polskaprzyjela,828794.html, 6.05.2019.

Dane zbiorcze za 2015, 2018 rok (2015, 2018), http://psz.praca.gov.pl/web/urzad-pracy/-/8180075zezwolenia-na-prace-cudzoziemcow, 6.05.2019.

Dane zbiorcze za I połowę 2018 roku (2018), http://psz.praca.gov.pl/web/urzad-pracy/-/8180075-zezwolenia-na-prace-cudzoziemcow, 6.05.2019.

Debata z premierem Polski Mateuszem Morawieckim na temat przyszłości Europy (2018), sesja plenarna w dniu 4.07.2018, http://www.europarl.europa.eu/plenary/pl/vod.html?mode=chapter\&vod Language $=$ PL\&vodId $=1530687922990 \#$, 8.05.2019. 
Decyzja Rady (UE) 2015/1601 z dnia 22 września 2015 roku ustanawiająca środki tymczasowe w obszarze ochrony międzynarodowej na rzecz Włoch i Grecji, Dz. U. UE L 2015.248.80.

Dochody budżetu państwa w 2017 roku (2017), Załącznik nr 1, https://www.senat.gov.pl/download/ gfx/senat/p1/.../3276/.../881__zalaczniki.pdf, 7.04.2019.

Economic Resilience Initiative (2019), https://www.eib.org/en/projects/initiatives/resilience-initiative/ index.htm.

Exposé premier Beaty Szydło (2015) - transcript, https://www.premier.gov.pl/expose-premier-beatyszydlo-stenogram.html, 2.11.2016.

First residence permits issued in the EU Member States remain above 3 million in 2017 (2018), "Newsrelease" Eurostat 25 November 2018, https://ec.europa.eu/eurostat/documents/2995521/ 9333446/3-25102018-AP-EN.pdf/3fa5fa53-e076-4a5f-8bb5-a8075f639167, 9.05.2019.

Instrument Pomocy dla Uchodźców w Turcji (2016): państwa członkowskie zgodne co do szczegółów finansowania, Komunikat prasowy Rady UE, 3.02.2016, https://www.consilium.europa.eu/pl/ press/press-releases/2016/02/03/refugee-facility-for-turkey/, 7.05.2019.

Interpelacja $n r 23257$ do ministra spraw zagranicznych $w$ sprawie zatrzymania procesu nielegalnego sprowadzania imigrantów do Polski (2018), zgłaszający: Anna Elżbieta Sobecka, data wpływu: 21.06.2018, http://www.sejm.gov.pl/Sejm8.nsf/InterpelacjaTresc.xsp?key=459B8BBD, 9.05.2019.

Interpelacja nr 26115 do prezesa Rady Ministrów w sprawie konieczności wstrzymania napływu imigrantów (2018), zgłaszający: Barbara Bubula, data wpływu: 12.09.2018, http://www.sejm.gov. pl/Sejm8.nsf/InterpelacjaTresc.xsp?key=B4WHGP, 9.05.2019.

Interpelacja $\mathrm{nr} 8801$ do ministra rodziny, pracy i polityki społecznej w sprawie polityki imigracyjnej (2016), zgłaszający: Adam Ołdakowski, Jerzy Małecki, data wpływu: 19.12.2016, http://www. sejm.gov.pl/Sejm8.nsf/InterpelacjaTresc.xsp?key=2D5C203B, 9.05.2019.

Kozłowska M. (2018), Morawiecki: nie będziemy przyjmowali uchodźców z Bliskiego Wschodu i Afryki Ptn., PAP 1.01.2018, https://www.pap.pl/aktualnosci/news\%2C1229759\%2Cmorawiecki-niebedziemy-przyjmowali-uchodzcow-z-bliskiego-wschodu-i-afryki-pln.html, 2.04.2019.

Łotocki Ł. (2019), Kryzys imigracyjny w Europie w polskim dyskursie publicznym w latach 2015-2018, Warszawa.

Maciejewicz P. (2016), Morawiecki i Waszczykowski w Davos: Jeśli chodzi o uchodźców, to już jesteśmy najlepsi, „Gazeta Wyborcza” 24.01.2016, http://wyborcza.pl/1,155290,19527773,morawieckii-waszczykowski-w-davos-jesli-chodzi-o-uchodzcow.html, 7.05.2019.

„Milion uchodźców z Ukrainy” (2016). Szymański: to nie seminarium naukowe, można mówić skrótem, 20.01.2016, https://www.tvn24.pl/wiadomosci-z-kraju,3/szydlo-o-milionie-uchodzcow-zukrainy-konrad-szymanski-komentuje,612409.html, 6.05.2019.

Merkel (2018): Polska przyjmuje uchodźców, choć może innych niż reszta UE, „Rzeczpospolita” 19.03.2018, http://www.rp.pl/Unia-Europejska/180319258-Merkel-Polska-przyjmuje-uchodzcow-choc-moze-innych-niz-reszta-UE.html, 6.04.2019.

Morawiecki w „Le Figaro” o Unii, Rosji, gospodarce, migracji i polskich reformach (2019), „Gazeta Prawna" 10.02.2019, https://www.gazetaprawna.pl/artykuly/1396915,morawiecki-w-le-figaroo-unii-rosji-gospodarce-migracji-i-polskich-reformach.html, 16.03.2019.

Morawiecki o „przyjmowaniu uchodźców z Ukrainy”. Szef ukraińskiego MSZ: my ratujemy polska gospodarke (2017), Polsat News, 9.12.2017, https://www.polsatnews.pl/wiadomosc/2017-12-09/ morawiecki-o-przyjmowaniu-uchodzcow-z-ukrainy-szef-ukrainskiego-msz-my-ratujemy-polska-gospodarke/, 9.05.2019.

More strategic focus would improve impact of Poland's foreign aid (2017), 14.02.2017, http://www. oecd.org/newsroom/more-strategic-focus-would-improve-impact-of-poland-foreign-aid.htm, 18.04.2019.

Nadzwyczajny fundusz powierniczy UE na rzecz Afryki (2015), Valetta, 12.11.2015, http://europa.eu/ rapid/press-release_MEMO-15-6056_pl.htm, 3.04.2019. 
Natolin Graduation Debate 2018 with Wolfgang Schäuble and Mateusz Morawiecki (2018), https:// www.youtube.com/watch?v=3IG29QOPEBU\&t=1s, 8.05.2019.

Nasz wywiad (2018). Gadowski: „Mówiąc o przyjęciu imigrantów szef MSZ wygadat się albo dat dowód swojej niekompetencji”. Rozmawiał T. Plaskota, wPolityce.pl, 11.04.2018, https://wpolityce.pl/polityka/389745-nasz-wywiad-gadowski-mowiac-o-przyjeciu-imigrantow-szef-mszwygadal-sie-albo-dal-dowod-swojej-niekompetencji, 8.04.2019.

New high in first residence permits issued in the EU Member States in 2016 (2017), "Newsrelease" Eurostat 16 November 2017, https://ec.europa.eu/eurostat/documents/2995521/8456381/316112017-BP-EN.pdf/e690a572-02d2-4530-a416-ab84a7fcbf22, 5.05.2019.

Nie przyjęliśmy żadnych uchodźców z relokacji (2018), „Rzeczpospolita”, 11.04.2018, http://www. rp.pl/Uchodzcy/180419862-MSZ-Nie-przyjelismy-zadnych-uchodzcow-z-relokacji.html, 12.04.2019.

Official Development Assistance 2018 - Preliminary Data (2018), https://www2.compareyourcountry. org/oda?page $=0 \& \mathrm{cr}=76 \& \mathrm{cr} 1=$ oecd $\& \lg =$ en, 18.04.2019.

Oświadczenie Ministerstwo Spraw Zagranicznych (2018), 11.04.2018, https://twitter.com/MSZ_ $\mathrm{RP} /$ status/984042632899907590/photo/1?ref_src=twsrc\%5Etfw\%7Ctwcamp\%5Etweet embed\%7Ctwterm\%5E984042632899907590\&ref_url=https\%3A\%2F\%2Fwww.tvn24. p1\%2Fwiadomosci-z-kraju\%2C3\%2Fuchodzcy-w-polsce-czaputowicz-mowi-ilu-polskaprzyjela\%2C828794.html, 12.05.2019.

Oświadczenia o powierzeniu wykonywania pracy cudzoziemcowi, wpisane do ewidencji oświadczeń w 2015, 2016, 2017, 2018, http://psz.praca.gov.pl/web/urzad-pracy/-/8180205-rejestracja-oswiadczen-pracodawcow-o-zamiarze-powierzenia-pracy-cudzoziemcowi, http://psz.praca.gov. pl/web/urzad-pracy/-/8180211-oswiadczenia-o-powierzeniu-wykonywania-pracy-cudzoziemcowi-wpisane-do-ewidencji-oswiadczen-obowiazujace-od-2018-r-, 5.05.2019.

Pawłowicz K. (2018a), Twitter 11.04.2018, https://twitter.com/KrystPawlowicz?ref_src=twsrc\%5Etfw \%7Ctwcamp\%5Etweetembed\%7Ctwterm\%5E984017950029045764\&ref_url=https\% 3A\%2F\%2Fwww.newsweek.pl\%2Fpolska\%2Fpolityka\%2Fjacek-czaputowicz-o-uchodzcachkrystyna-pawlowicz-reaguje\%2Fkgbqsj8, 17.04.2019.

Pawłowicz K. (2018b), Twitter, 20.06.2018, https://twitter.com/KrystPawlowicz/status/101006931923 6153344/photo/1?ref_src=twsrc\%5Etfw\%7Ctwcamp\%5Etweetembed\%7Ctwterm\%5E10100 69319236153344\&ref_url=https\%3A\%2F\%2Fwww.fakt.pl\%2Fwydarzenia\%2Fpolityka\%2F krystyna-pawlowicz-pisze-list-do-premiera-ws-migrantow\%2F50vzxxz, 17.04.2019.

Plan wspótpracy rozwojowej w 2018 r. (2018), MSZ, Warszawa grudzień 2018.

Polska przekazuje 50 milionów euro na inicjatywę wspierająca kraje dotknięte kryzysem migracyjnym (2017), 6.12.2017, http://polskapomoc.gov.pl/Polska,przekazuje,50,milionow,euro,na,inicjaty we,wspierajaca,kraje,dotkniete,kryzysem,migracyjnym,2708.html, 18.04.2019.

Polska Wspótpraca Rozwojowa (2018). Raport Roczny 2017, MSZ, Warszawa 2018, https://www.polskapomoc.gov.pl/Publikacje,2794.html, 15.04.2019.

Potyrała A. (2018), Unijny system relokacji w sprawozdaniach Komisji Europejskiej. Ocena i perspektywy, „Przegląd Politologiczny”, no. 2.

Premier Beata Szydlo w Londynie: Polska przekaże 3 mln euro na pomoc humanitarna dla Syrii (2016), 4.02.2016, https://www.premier.gov.pl/wydarzenia/aktualnosci/premier-beata-szydlo-w-londynie-polska-przekaze-3-mln-euro-na-pomoc.html, 18.04.2019.

Premier Beata Szydło: ok. 4 mln zł na odbudowę domów w Syrii (2017), 11.04.2017, https://www.premier.gov.pl/wydarzenia/aktualnosci/premier-beata-szydlo-ok-4-mln-zl-na-odbudowe-domoww-syrii.html, 15.04.2019.

Premier Mateusz Morawiecki (2018b): Nasza polityka zagraniczna to polityka polskiej racji stanu, 2.07.2018, https://www.premier.gov.pl/wydarzenia/aktualnosci/premier-mateusz-morawieckinasza-polityka-zagraniczna-to-polityka-polskiej.html, 2.05.2019. 
Premier Mateusz Morawiecki z wizyta w Libanie (2018c), 13.02.2018, https://www.premier.gov.pl/ wydarzenia/aktualnosci/premier-mateusz-morawiecki-z-wizyta-w-libanie.html, 2.05.2019.

Premier po nieformalnym szczycie UE: racja Polski ws. migracji została podtrzymana (2018a), 20.09.2018, https://www.premier.gov.pl/wydarzenia/aktualnosci/premier-po-nieformalnymszczycie-ue-racja-polski-ws-migracji-zostala.html, 2.05.2019.

Prezydent „absolutnie negatywnie” o próbach naktadania na Polskę kar ws. relokacji (2017), 13.06.2017, https://www.prezydent.pl/aktualnosci/wypowiedzi-prezydenta-rp/wystapienia/ art,237,prezydent-absolutnie-negatywnie-o-probach-nakladania-na-polske-kar-ws-relokacji-. html, 30.05.2019.

Prezydent dla PAP (2017): Potrzebna reforma wymiaru sprawiedliwości i zmiany w konstytucji. Rozmawiali C. Bielakowski i T. Grodecki (PAP), 24.05.2017, https://www.prezydent.pl/aktualnosci/wypowiedzi-prezydenta-rp/wywiady/art,109, prezydent-dla-pap-potrzebna-reforma-wymiaru-sprawiedliwosci-i-zmiany-w-konstytucji-.html, 17.04.2019.

Residence permits for non-EU citizens EU Member States issued 2.3 million first residence permits in 2014 (2015), "Newsrelease" Eurostat 20 October 2015, https://ec.europa.eu/eurostat/documents/2995521/7038745/3-20102015-BP-EN.pdf/70063124-c3f2-4dfa-96d5-aa5044b927a6, 9.04.2019.

Rozmowy niedokończone (2017): Przyszłość gospodarcza i finansowa Polski, TRWAM, 8.12.2017, http://www.radiomaryja.pl/informacje/rozmowy-niedokonczone-udzialem-premiera-mateusza-morawieckiego/, 15.05.2019.

Rozmowy niedokończone (2018): Bezpieczeństwo wewnętrzne Polski, cz. I, TV TRWAM 20.09.2018, http://www.radiomaryja.pl/multimedia/audio/rozmowy_niedokonczone/rozmowy-niedokonczone-bezpieczenstwo-wewnetrzne-polski-cz-i/, 6.04.2019.

Rozporządzenie Prezesa Rady ministrów z dnia 5 stycznia 2018 r. w sprawie szczegółowego zakresu działania Ministra - Członka Rady Ministrów Beaty Kempy (2018), Dz. U. 2018, poz. 46.

Rząd (2016): Polska nie jest w stanie w tej chwili przyjąc imigrantów, „Gazeta Prawna” 23.03.2016, https://www.gazetaprawna.pl/artykuly/929697,rzad-polska-nie-jest-w-stanie-przyjac-imigrantow.html, 15.05.2019.

Rząd chce ściagnać pracowników z Filipin (2018), „Nasz kraj jest bliski kulturowo”, TVN24BIS, 28.07.2018, https://tvn24bis.pl/z-kraju,74/polska-chce-sciagnac-pracownikow-z-filipin, 857116.html, 2.04.2019.

Rząd i stowarzyszenie „Pomoc Kościołowi w Potrzebie” dla Syrii (2017), KAI 2.03.2017, https://ekai. $\mathrm{pl} /$ rzad-i-stowarzyszenie-pomoc-kosciolowi-w-potrzebie-dla-syrii/, 6.06.2019.

Spotkanie z ministrem Markiem Suskim na temat polityki migracyjnej rzadu RP w Instytucie Polskim w Wiedniu (2018), 21.04.2018, https://www.premier.gov.pl/wydarzenia/aktualnosci/spotkaniez-ministrem-markiem-suskim-na-temat-polityki-migracyjnej-rzadu-rp-0.html, 7.05.2019.

Sprawozdanie stenograficzne z 100. posiedzenia Sejmu Rzeczypospolitej Polskiej w dniu 16 września 2015 r. (2015), Warszawa 2015, http://orka2.sejm.gov.pl/StenoInter7.nsf/0/A8CA0F4060DE3 B1CC1257EC200722812/\%24File/100_a_ksiazka.pdf, 1.03.2016.

Sprawozdanie stenograficzne z 15. posiedzenia Sejmu Rzeczypospolitej Polskiej w dniu 1 kwietnia $2016 r$. (2016), http://orka2.sejm.gov.pl/StenoInter8.nsf/0/49D91ACEDB27E6B0C1257F880 05E9B82/\%24File/15_c_ksiazka_bis.pdf, 1.03.2016.

Strzałkowski P. (2019), Morawiecki obiecał miliony na domy dla uchodźców w Libanie. Po roku rząd milczy na ich temat, „Gazeta Wyborcza” 30.01.2019, http://wiadomosci.gazeta.pl/wiadomos ci/7,114881,24406514,morawiecki-obiecal-miliony-na-domy-dla-uchodzcow-w-libanie.html, 14.5.2019.

Strzępka K. (2017), KE zdecydowała o procedurze wobec krajów, które nie przyjmuja uchodźców, PAP, 13.06.2017, https://www.pap.pl/aktualnosci/news\%2C973226\%2Cke-zdecydowala-oprocedurze-wobec-krajow-ktore-nie-przyjmuja-uchodzcow.html, 5.05.2019. 
Syria (2016), https://webarchive.nationalarchives.gov.uk/20180312081846/https://www.supportingsyria2016.com/about/, 5.05.2019.

Syria, https://pkwp.org/t/felietony/syria.

Szczęch R. (2018), Odpowiedź na interpelację nr 12928 w sprawie utworzenia korytarzy humanitarnych $w$ Polsce, Warszawa 9.01.2018, http://www.sejm.gov.pl/sejm8.nsf/InterpelacjaTresc. $\mathrm{xsp}$ ?key=7CBB1E35, 15.05.2019.

Szczyt na Malcie (2015): Polska przekaże 1 mln euro na fundusz powierniczy dla Afryki, 12.11.2015, https://www.pap.pl/aktualnosci/news\%2C429971\%2Cszczyt-na-malcie-polska-przekaze-1-mln-euro-na-fundusz-powierniczy-dla-afryki-.html, 6.05.2019.

Szef MSWiA przed narada UE ws. uchodźców (2017): , Wywieranie presji na Polskę to prosta droga, która prowadzi do katastrofy społecznej”, 18.05.2017, https://wpolityce.pl/polityka/340268szef-mswia-przed-narada-ue-ws-uchodzcow-wywieranie-presji-na-polske-to-prosta-drogaktora-prowadzi-do-katastrofy-spolecznej, 20.05.2019.

Szef MSZ: przyjęliśmy 2700 migrantów (2018). Karczewski: nic nie wiem, „Rzeczpospolita”, 11.04.2018, http://www.rp.p1/Uchodzcy/180419870-Szef-MSZ-Przyjelismy-2700-migrantowKarczewski-Nic-nie-wiem.html, 9.05.2019.

Szydło o uchodźcach (2015), „Gość Niedzielny”, 1.09.2015, https://www.gosc.pl/doc/2679178.Szydloo-uchodzcach, 2.05.2019.

Szydło (2016a): nie ma możliwości, żeby do Polski przyjechali imigranci. Polska premier krytykuje Angele Merkel, „Superstacja” 23.03.2016, http://www.superstacja.tv/wiadomosc/2016-03-23/ szydlo-nie-ma-mozliwosci-zeby-do-polski-przyjechali-imigranci-polska-premier-krytykujeangele-merkel/, 20.05.2019.

Szydło B. (2016b), wystąpienie na 19. Posiedzeniu Sejmu w dniu 20 maja 2016, p. 283, http://orka2. sejm.gov.pl/StenoInter8.nsf/0/16FA36F943CF9987C1257FB9008352F2/\%24File/19_c_ ksiazka_bis.pdf, 8.04.2019.

Szymański D. (2018), Pawet Chorąży zdymisjonowany. Wiceminister ,zagalopowat się” w stowach o imigrantach, 14.09.2018, https://businessinsider.com.pl/wiadomosci/wiceminister-inwestycji-i-rozwoju-pawel-chorazy-zdymisjonowany/z75j6b4, 12.04.2019.

Uchwała Sejmu Rzeczypospolitej Polskiej z dnia 1 kwietnia 2016 r. w sprawie polityki imigracyjnej Polski (2016a), M. P. 2016, poz. 370.

Uchwała Sejmu Rzeczypospolitej Polskiej z dnia 2 grudnia 2016 r. w sprawie propozycji ustanowienia unijnego korekcyjnego mechanizmu alokacji uchodźców oraz mechanizmu solidarności finansowej (2016b), M.P. 2016, poz. 1183.

Uchwała Sejmu Rzeczypospolitej Polskiej z dnia 20 maja 2016 r. w sprawie obrony suwerenności Rzeczypospolitej Polskiej i praw jej obywateli (2016c), M. P. 2016, poz. 466.

Ustawa z dnia 16 września 2011 r. o wspótpracy rozwojowej (2019), Dz. U. 2019, poz. 291.

Ustawa z dnia 9 listopada 2000 r. o repatriacji (2018a), Dz. U. 2018, poz. 609.

Ustawa z dnia 7 września 2007 roku o Karcie Polaka (2018b), Dz. U. 2018, poz. 1272.

,,Walcza z rządem, używając jako tarczy dzieci z Aleppo”. Kempa w „, Gościu Wydarzeń” (2017), Polsat News 27.02.2017, https://www.polsatnews.pl/wiadomosc/2017-02-27/walcza-zpolskim-rzadem-uzywajac-jako-tarczy-dzieci-pokrzywdzonych-wojna-w-aleppo-kempa-oprzyjmowaniu-uchodzcow/,1.06.2019.

Wiceminister inwestycji i rozwoju (2018): Polska i musi a nawet, jeśli nie musi, powinna chcieć imigrantów [WIDEO], 31.08.2018, https://dzienniknarodowy.pl/wiceminister-inwestycjirozwoju-polska-musi-a-nawet-jesli-musi-chciec-imigrantow-wideo/, 7.04.2019.

Wychowałem się w „trójkącie bermudzkim” (2018), „Gość Niedzielny” 4.01.2018, https://www.gosc. pl/doc/4408019. Wychowalem-sie-w-trojkacie-bermudzkim, 1.06.2019.

Wyniki konkursu (2017) „Pomoc humanitarna na Bliskim Wschodzie w zakresie przygotowania ludności do zimy 2017”, 27.09.2017, http://polskapomoc.gov.pl/Wyniki,konkursu,Pomoc,hum 
anitarna,na,Bliskim,Wschodzie,w,zakresie,przygotowania,ludnosci,do,zimy,2017,2661.html, 6.05.2019.

Wyniki konkursu (2018) „, Pomoc humanitarna na Bliskim Wschodzie 2018”, 21.03.2018, http://polskapomoc.gov.pl/Wyniki,konkursu,Pomoc,humanitarna,na,Bliskim,Wschodzie, 2018,2740.html, 6.05.2019.

Wyniki konkursu (2019a) „Pomoc humanitarna na Bliskim Wschodzie 2019”, 11.04.2019, http://polskapomoc.gov.p1/Wyniki,konkursu,Pomoc,humanitarna,na,Bliskim,Wschodzie,2019,2928. $\mathrm{html}$, 6.05.2019.

Wyniki konkursu Polska pomoc rozwojowa 2019 (2019b), 18.03.2019, http://polskapomoc.gov.pl/ Wyniki,konkursu,Polska,pomoc,rozwojowa,2019,2918.html, 6.05.2019.

Wystapienie Prezesa PiS podczas V Kongresu Programowego Prawa i Sprawiedliwość w Przysusze (2017), 1 lipiec 2017, http://pis.org.pl/aktualnosci/jest-w-nas-wiara-w-przyszlosc-i-w-polske, 1.06.2019.

Wywiad $z$ premierem M. Morawieckim dla CNN (2016), https://www.youtube.com/ watch? $\mathrm{v}=$ gksyz6s2tvU, 4.04.2019.

Zestawienie roczne (2015), https://udsc.gov.pl/statystyki/raporty-okresowe/zestawienia-roczne/, 3.04.2019.

Zestawienie roczne (2016), https://udsc.gov.pl/statystyki/raporty-okresowe/zestawienia-roczne/, 3.04.2019.

Zestawienie roczne (2015-2018), https://udsc.gov.pl/statystyki/raporty-okresowe/zestawienia-roczne/, 3.04.2019.

Zestawienie roczne (2018), https://udsc.gov.pl/statystyki/raporty-okresowe/zestawienia-roczne/, 3.04.2019.

Zezwolenia na pracę cudzoziemców w 2015, 2016, 2017, 2018, http://psz.praca.gov.pl/web/urzadpracy/-/8180075-zezwolenia-na-prace-cudzoziemcow, 3.04.2019.

\section{Zaklinanie rzeczywistości. \\ Stanowisko polskiego rządu wobec imigracji po 2015 roku}

\section{Streszczenie}

Celem niniejszego artykułu jest analiza polskiej polityki migracyjnej po 2015 roku. Autorka chciałaby ukazać rozbieżności między politycznymi deklaracjami a rzeczywistością. Celem artykułu jest także pokazanie stanowiska rządu Prawa i Sprawiedliwości wobec polityki UE w sprawie rozwiązania kryzysu migracyjnego oraz otwartości Polski na rzecz przyjęcia uchodźców/imigrantów. W artykule postawiono tezę, że polityka migracyjna polskiego rządu w latach 2015-2019 była niespójna.

Słowa kluczowe: imigranci, uchodźcy, relokacja, polska polityka migracyjna 